\title{
Public Housing for Lower-Middle-Income Families: New Jersey's State Housing \\ Program in the Late 1940s
}

\section{By Keisuke Jinno}

\section{DOI: http://dx.doi.org/10.14713/njs.v4i2.126}

This article addresses a lost housing alternative at the dawn of post-New Deal, homeownercentered America. At the end of the 1940s, the State of New Jersey attempted to launch a state public housing program for lower-middle-income families who had been left out of both the private market for prospective homeowners and the existing public housing projects. The program, however, was incompatible with business-backed plans to create a mass homeownership society. Galvanized by anti-tax sentiment among current and prospective homeowners, voters rejected a state housing bond referendum necessary to the program. An additional factor was white residents' politics of exclusion that produced anti-public housing hysteria. Finally, plan proponents' lack of consensus about financial resources and grass-roots activities failed to sway public opinion and resulted in low voter turnout in central places.

The State of New Jersey proposed a modern public housing program for lower-middleincome families at the end of the 1940s. It was the Garden State's little known attempt at a majority-oriented public housing. ${ }^{1}$ During the New Deal era, the Housing Division of the Public Works Administration (PWA) had pioneered a federal housing program oriented to middle-income families despite the insufficient scale of the program for its goal. The Housing Act of 1934 created the Federal Housing Administration (FHA) to provide federal mortgage insurance to encourage homeownership, and the Housing Act of 1937 produced many public projects that accommodated

\footnotetext{
1 In this article, "public housing" is defined as any dwelling owned, subsidized, or financed, and regulated in its principal operations (e.g. setting rents or selecting tenants), by the federal, state, or municipal government, including the housing authority.
} 
part of the working-class population. Yet the majority of lower- and middle-income families remained out of both the existing projects and the private market for prospective homeowners. ${ }^{2}$ The National Housing Agency (NHA), in 1944, published a projection on U.S. housing needs for the first decade after the war, based on the estimations of population increases, returning veterans, doubling-up married families, and substandard units. It estimated that only a half of the total 12.6 million new dwellings could be accomplished by the established private industries using FHA aids. $^{3}$ Working-class families feared income decreases that might follow the end of wartime production and cost increases after the end of rent control. In large cities, evictions and rent hikes had threatened great numbers of working-class tenants. ${ }^{4}$ It was therefore reasonable for housing reform advocates in the 1940s to seek to expand and reinforce public housing policy. Meanwhile, opponents of public housing gained confidence in building a broad-based homeownership society after World War II. A political alliance between conservative Republicans and southern Democrats, in tandem with real estate and bank lobbies, had generated a strong headwind against liberal housing reforms. The Veterans' Emergency Housing Program, which intended to facilitate through price controls construction of affordable housing for veterans, was wound down by the end of 1946. The Wagner-Ellender-Taft housing bill, the other postwar program aiming at a half-million units of public housing within a four-year period, had been blocked at the House Banking and Currency Committee until the 1948 election. Making public housing options more accessible and more attractive for the wider population would be incompatible with the promotion of a mass homeownership society.

\footnotetext{
2 Nathaniel S. Keith, Politics and the Housing Crisis since 1930 (New York: Universe Books, 1973), 58-100. Richard O. Davies, Housing Reform During the Truman Administration (Columbia, MO: University of Missouri Press, 1966), 10-39, 44-54, 67, 102-112.

3 Keith, 51.

4 Mark Naison, "From Eviction Resistance to Rent Control: Tenant Activism in the Great Depression," in Ronald Lawson ed., The Tenant Movement in New York City, 1904-1984 (New Brunswick, NJ: Rutgers University Press, 1986), 125-133.
} 
In retrospect, the late 1940s, when the State of New Jersey sought a new possibility in public housing policy, was a transitional period in the U.S. housing history. It ended up in a victory of the business-oriented postwar vision. After the 1950s, a so-called two-tier housing policy, which on the one hand popularized private homeownership by guaranteeing mortgage insurance, while on the other hand provided a limited scale of public housing projects only available to those in the lowest-income brackets, gained ascendancy. ${ }^{5}$ New Jersey witnessed such transformations. The homeownership rate in New Jersey was considerably lower than the U.S. average before World War II, but since 1950 it has resembled rates typical throughout the United States. ${ }^{6}$

This article addresses two closely related issues in the historiography of U.S. housing policy. First, it emphasizes possibilities and uncertainty in the aftermath of World War II. It owes its basic concept of majority-oriented public housing to Gail Radford's accounts of the New Deal period. While Radford believes that the 1937 Act represented a shift towards a two-tiered system, the findings in this New Jersey case shows that different possible paths still existed in the late 1940s. Secondly, it explores the reasons why public housing for the broad and diverse population failed to be an option in the postwar American politics. Historians who focus on national-level politics have argued that disproportionately powerful conservatives and resourceful business themselves were responsible for this outcome. ${ }^{7}$ To be sure, these traditional anti-New Deal forces played significant roles in decelerating reform politics. Not many scholars, however, have addressed how ordinary people viewed the policy controversies and why public attention to public housing faded

\footnotetext{
5 Gail Radford, Modern Housing for America: Policy Struggles in the New Deal Era (Chicago: University of Chicago Press, 1996), 85-109, 179-209.

6 U.S. Census Bureau, Historical Census of Housing Tables. [www.census.gov/hhes/www/housing/census/historic/owner.html]. In New York State, in contrast, where multifamily constructions dominated, lower homeownership rates were the norm even after 1950.

7 Rachel G. Bratt, Rebuilding a Low-Income Housing Policy (Philadelphia: Temple University Press, 1989), 55-56; R. Allen Hays, Federal Government and Urban Housing, Third Edition (Albany: State University of New York Press, 2012), 95-102; Keith, 29-30, 37-39; Davies, 102-115.
} 
by the early 1950s. Examining state-level politics, including referendum records, this article approaches the depth of sociopolitical dynamics in the critical period. Other than the fact that there were substantial efforts to upgrade public housing policy in the late 1940s, it clarifies that the defeat of majority-oriented public housing options was caused, not simply by business-backed oppositions, but more importantly by the political turnabout of current and prospective homeowners, including former New Deal supporters, the white working class. Even though this study is limited to New Jersey's housing history, it nevertheless introduces a new perspective to general histories about the demise of the postwar New Deal and the consolidation of two-tier housing policy in the United States.

\section{The Origins of the New Jersey State Housing Program}

New Jersey had a serious housing crisis during the aftermath of World War II, despite implementing federal public housing projects in 1938 and the state Emergency Veterans Housing Program in 1946 . The state had built 8,838 public housing units by the summer of $1944 .^{8}$ Immediately after the war, another low-rent 6,156 units were provided for veterans and other distressed families under the state veterans program. ${ }^{9}$ There were still approximately 250,000 substandard housing units across the state in the late 1940s. One-fifth of all dwelling units in the largest ten cities of northeastern New Jersey were substandard. ${ }^{10}$ According to a local survey held

\footnotetext{
8 State of New Jersey, Final Report of The State Housing Authority (1 July 1944), 1. New Jersey State Library: Government Document Section, Trenton, NJ (hereafter: NJSL).

9 New Jersey State Department of Economic Development, Public Housing and Development Authority, Interim Report on Emergency Housing for Veterans (7 April 1947), 6. NJSL.

${ }^{10}$ Bureau of the Census, U.S. Department of Commerce, The United States Census, 1940, Housing: Second Series: General Characteristics: New Jersey (Washington D.C.: Government Printing Office, 1942). Bureau of the Census, U.S. Department of Commerce, The United States Census, 1950, Housing: Chap. 30: General Characteristics: New Jersey (Washington D.C.: Government Printing Office, 1952). The largest 10 cities in northeastern New Jersey at the time were Newark, East Orange, Irvington, Elizabeth, Jersey City, Bayonne, Hoboken, Union City, Paterson, and Passaic. The Census shows the total number of substandard units across the state was 290,000 [23.7 percent of all housing units] in 1940 and 248,000 [ 16.5 percent] in 1950. The term of "substandard housing" is defined as dilapidated dwellings that need major repairs or those with no private bath, no toilet, or no running water, excluding unreported dwellings.
} 
in December of 1947, 64 percent of home renters in New Jersey were dissatisfied with their living quarters, and another poll showed 62 percent of the people answered "housing" or "high cost of living" as the biggest problem they confronted. ${ }^{11}$ A 1948 state survey indicated that there was a tremendous need for rental units between $\$ 45$ and $\$ 55$, about the maximum acceptable price range for typical working-class renters in urban New Jersey at the time. ${ }^{12}$

The New Jersey State CIO Council (NJ-CIO), which represented 170,000 workers, was the major social actor that called for a new state housing policy. The NJ-CIO's survey on housing conditions among union members during the winter of 1947 demonstrated that about half of them were living in substandard units without adequate space, baths, toilets, or proper heating and that nearly half of its members were under threat of eviction. Many working-class families could not yet obtain adequate purchasing power to get ownership of a decent home. Organized labor viewed this as a failure of the private market. "The glaring truth is that decent low-cost housing for sale or rent is not findable" because private business "has shown itself uninterested and unwilling" to provide decent low-rent housing, testified Carl Holderman, president of the NJ-CIO, before the joint Congressional Committee on Housing in November $1947 .^{13}$

In January 1948, executive officers of the NJ-CIO met with Republican Governor Alfred E. Driscoll seeking his endorsement of their legislative program, including continuation of state rent control and their tax proposal. ${ }^{14}$ The NJ-CIO proposed a comprehensive tax program with "two types of equitable taxes [based] on the principle of ability to pay," namely a state individual

\footnotetext{
11 Princeton Research Service, The New Jersey Poll, 25 August 1948; 19 May 1949, Sinclair New Jersey Collection, Special Collections and University Archives, Rutgers University, New Brunswick, NJ (hereafter: SNJC).

12 "Legislative Note," The State of New Jersey, Judiciary Committees of the Senate and the General Assembly, Legislative Bulletin on the Low Rent Housing and Slum Clearance Program, Proposed by Governor Alfred E. Driscoll on March 28, 1949 (hereafter Legislative Bulletin, 1949) 11, Government Documents of New Jersey, Alexander Library, Rutgers University, New Brunswick, NJ (hereafter: DOCNJ).

${ }^{13}$ New Jersey CIO News, December 1947, 5.

${ }^{14}$ New Jersey CIO News, February 1948, 3.
} 
income tax on upper- and upper-middle-income brackets and a state corporate income tax on highprofit corporations. They estimated a one percent tax on individual incomes exceeding $\$ 5,000$ per year would generate about $\$ 40,000,000$ in state revenue, and an imposition of a four percent tax on the net profits exceeding $\$ 25,000$ a year would apply to 3,100 of 16,000 corporations in New Jersey and would raise an additional $\$ 47,000,000$ per year. The union federation asserted that the majority of the funds from these income-based revenues would be spent on new social policies including state-operated health insurance and state public housing. ${ }^{15}$

An innovative program, which inspired housing reformers in New Jersey, had already shown progress across the Hudson. The State of New York initiated its own public housing program in 1938 with an original investment of $\$ 300$ million in housing bonds and $\$ 5$ million in annual subsidies. The program, which caught the attention of Trenton, was expanded in 1947 with an additional $\$ 135$ housing bond and an increase in maximum subsidies from $\$ 9$ to $\$ 13$ million per year. By the end of 1948, about 30,000 units had already been built or planned for lower- and middle-income residents under the New York State housing program. ${ }^{16}$

With the reality of a serious housing crisis and demands from labor unions, veterans' organizations, and other social groups in New Jersey, Democratic Assemblyman Jacob Friedland

\footnotetext{
15 New Jersey State CIO Council, A Comprehensive Tax Program for New Jersey, 1948, 5-6, SNJC. The rest of the funds were expected to be given to many municipalities for other purposes including to "relieve property owners from their present staggering load in most municipalities."

16 "The New York Law on Housing Aid: Memorandum from William T. Vanderlipp to Commissioner Charles R. Erdman, Jr.," 18 October, 1945. Folder: N.Y. State Public Housing Law, Box 8A, Department of Conservation and Economic Development, Commissioner's Office, Subject Files, 1920s-1960s, New Jersey State Archives, Trenton, NJ (hereafter: NJSA); New York City Board of Elections, Annual Report of the Board of Elections of the City of New York, 1938; "Brief Summaries of 9 Amendments," New York Times, 6 November 1938, 43; "Votes for Housing Urged by Leaders," New York Times, 7 November 1938, 3; "Amendments Vote Closest on No.1," New York Times, 10 November 1938, 12; "Tabulated Results of the Voting Yesterday in the City and Suburbs," New York Times, 5 November 1947, 12; Edward W. Bates, "Dewey to Ask Doubled Aid for Housing," New York Herald Tribune, 19 December 1948; Book 862, Box 78, Driscoll Records, Journal of Housing, December 1949, 425; Book 875, Box 79, Driscoll Records. For the New York City's public housing programs for middle-income families after World War II, see Joshua B. Freeman, Working-Class New York: Life and Labor Since World War II (New York: The New Press, 2000), 109-114
} 
from Hudson County introduced a set of bills in February 1948 to launch a new state housing policy. ${ }^{17}$ The Friedland bills, the main piece of which was Assembly Bill no. 189 (A-189), aimed to initiate a new state public housing program through long-term and low-interest state loans and supplemental state subsidies to municipalities and local housing authorities. ${ }^{18}$ The bills were not simply asking for additional slum-replacing public projects, but rather they authorized the state to fill the gap between low-income public housing and homeowner protection.

First, A-189 conferred "complete power" to the State Department of Economic Development (DED, later DCED) to manage every aspect of the state housing program, including rent levels and qualification standards, which meant the DED could override any local barrier, such as municipal debt limitations or zoning ordinances. Moreover, A-189 permitted the state to buy necessary land and properties to establish its own housing projects. In short, the state could create any type of public housing. ${ }^{19}$ Second, tenant households qualified for the program if their annual income fell below $\$ 3,500$, which was close to the median income in New Jersey at the time. ${ }^{20}$ Tenants already living in state projects would remain qualified unless their annual income went over $\$ 4550$, or 30 percent greater than the original threshold. A-189 did not limit state housing to those with the lowest incomes but promised housing for middle-income working-class families who had not qualified for federal public housing projects. There was no provision to require state

\footnotetext{
17 State of New Jersey, Minutes of the Votes and Proceedings of the General Assembly of the State of New Jersey, 1948 (Trenton, 1948) 140-141, 147, 185, DOCNJ.

18 The maximum term of reimbursement of state loans was 50 years, and the interest rate was less than 3 percent. The maximum state subsidy for each project was equal to the interest charges on the state loan plus 1 percent of the project's total cost, up to $\$ 150,000$ per annum. Section 15 (c): Assembly Bill, No. 189 (A-189), Book 378: Correspondences - Assembly Bills 160-200, 1948, Box 033, Governor Alfred E. Driscoll Records, Series I, Driscoll Records, NJSA.

19 Section 3, 6-8: A-189, Book 378, Box 033, Driscoll Records.

${ }^{20}$ Bureau of the Census, The U.S. Census, Population, 1950, New Jersey (Washington D.C.: Government Printing Office, 1952). Section 9: A-189, Book 378, Box 033, Driscoll Records. The 1950 Census shows the median income was $\$ 3,484$ in Hudson County [where 84.3\% of the employed labor force were non-exempt workers], $\$ 3675$ in Passaic County [id., 81.8\%], and \$3,769 in Essex County [id., 77.9\%]. Therefore, the median working-class income in New Jersey at the time was most likely less than $\$ 3,500$.
} 
housing be erected in slum areas. Third, A-189 clearly prohibited discrimination in every state housing project. ${ }^{21}$ As for financial resources, A-189 disregarded the NJ-CIO's income-based equitable taxation proposal. Instead, it envisioned a fund secured primarily by $\$ 100,000,000$ in state housing bonds, which had to be approved by the referendum. ${ }^{22}$ Due to the reimbursement obligation of the state, which borrowed the capital by issuing the housing bonds, contractors and local housing authorities that received state housing loans to construct public projects were obligated to pay off the principal and interest. The contractors were expected to do so out of their operating revenues - and not from general tax revenues. Thus the measures were said to be largely "self-liquidating." This "self-liquidating" aspect, not primarily relying on tax revenues, limited the function of income redistribution that usually supported social welfare. Still, there was room for a plan in which it was at the same time possible to lower rents, enhance quality, and expand the scale of the entire program. Compared with private loans, state housing loans, because of their longerterms and lower-interest rates from housing bonds, significantly reduced the local housing authorities' reimbursement terms and interest rates. Also properties under the state housing program were partially tax-exempt. Combining these favorable conditions with the non-profit nature of housing authorities, rents could be lower than those charged by their private counterparts. Moreover, despite the "self-liquidating" label, the program would provide local housing authorities that faced difficulty in meeting reimbursement obligations with state housing subsidies that were appropriated from general funds. With this subsidy, the proposed state housing program was not entirely "self-liquidating." In addition, it authorized any municipality or local housing authority to raise money notwithstanding any law restricting municipal debt or local bond. ${ }^{23}$ If the state

${ }^{21}$ Section 18: A-189, Book 378, Box 033, Driscoll Records.

22 Section 20: A-189, Section 1, 2, 5, 8, 17: A-188, Book 378, Box 033, Driscoll Records.

${ }^{23}$ Section 12, 13, 16: A-189, Book 378, Box 033, Driscoll Records. 
increased the subsidies and local governments raised additional funds, the entire capital available for the state housing program would expand far beyond $\$ 100$ million.

Within a few months after the introduction of the Friedland bills, various pro-reform groups, including the NJ-CIO, Essex Trades Council of the American Federation of Labor (AFL), Newark District Union Council of the CIO, American Veterans' Committee, Visiting Nurses' Association, New Jersey Urban League, Newark Welfare Council, and Newark Housing Authority convened to set up an interim committee on housing reform. They united in full support of the principles set forth in the Friedland bills and the Wagner-Ellender-Taft Housing Bill. ${ }^{24}$ In May 1948, they established the New Jersey Housing Council (NJHC), which became the largest coalition to support housing reform in the state. The NJHC resolution demanded an expansion of public housing coverage to middle-income families urging "the enactment of state legislation for the construction of housing projects ... for those in the low and middle income brackets." 25 The formation of the NJHC indicated the potential a majority-oriented public housing policy would have to raise broad-based endorsements from the public. ${ }^{26}$

The groups in the NJHC could not, however, reach an agreement on the issue of financing. Some groups argued that the state housing program "can be $100 \%$ self-liquidating," and other groups asserted that at least some portion of the funds to reimburse the state housing bonds should "come out of the taxpayers' pocket." 27 A completely self-liquidating program would be more easily accepted by politicians, but it would impose tremendous limits on the scale, quality, and rent

\footnotetext{
${ }^{24}$ Letter from Edward L. Parker (chairman of the interim committee: Board of Christian Social Relations of the Episcopal Diocese) to Governor Alfred E. Driscoll (15 March 1948), Book 378, Box 033, Driscoll Records.

25 "Summary of Minutes of Meeting of New Jersey Housing Council" (6 May 1948), Book 378, Box 033, Driscoll Records.

26 State of New Jersey, Report of Public Hearing on Assembly Bill Nos. 45 and 48: Before the Judiciary Committees of the Senate and General Assembly, held on May 5, 1949, 2-4, DOCNJ.

27 "Summary of Minutes of Meeting of New Jersey Housing Council” (6 May 1948), Book 378, Box 033, Driscoll Records.
} 
affordability of the state housing projects. Therefore, lack of agreement on using tax revenue made their vision less persuasive, especially because their goal was to create high-quality and low-rent public housing units that that were available to as many people as possible. The NJHC as a statewide association lobbied in Trenton and sent their messages through mass media, but it did not have a collective movement agenda to change public minds through the grass-roots activities of the local member groups.

\section{New Jersey Housing Act of 1949}

The victory of Truman and the congressional Democrats in the 1948 general election enabled a new federal public housing bill projecting 1,050,000 units, though the goal would later be reduced to 810,000 units. The election result, along with widespread demands for low-rent housing among lower-middle-income families, influenced the attitude of the New Jersey's state government. Soon after the election, Charles R. Erdman Jr., the Commissioner of the Department of Conservation and Economic Development (DCED), urged Governor Driscoll to embark on a new housing policy, by stating that "the failure of the $80^{\text {th }}$ Congress to take constructive steps on this [housing] issue apparently contributed to the public disapproval of its records. Consequently, we will undoubtedly get action in housing at the next session."28

In January 1949, Governor Driscoll announced his intentions to create a New Jersey state public housing program. In his statement to the state legislature, Driscoll clarified that "medium and low income families ... are the people this program is designed to help" by building decent "housing that can be rented well under $\$ 50$ a month." Driscoll personally believed that his state housing initiatives would "stem the tide of nationalism and ever-increasing Federal control" and

\footnotetext{
28 Letter from Commissioner Charles R. Erdman, Jr. to Governor Alfred E. Driscoll (15 November 1948), Book 862, Box 078, Driscoll Records.
} 
"radical revulsion that engulf our American free institutions." 29 Whatever thoughts he had, the proposal to create public housing for middle-income families was "radical" enough to astound the real estate industry. ${ }^{30}$ He exaltedly described the plan, which was embodied in bills by the end of March, as the "most comprehensive housing program in the United States." 31 The plan to construct 45,000 units including "apartment houses of all types and single-family dwellings," was, indeed, "comprehensive" in a qualitative rather than quantitative sense. Some local newspapers featured the new state housing program with photos of two- and three-story apartments and single detached homes, not high-rise constructions. ${ }^{32}$ The Republican majority in the state legislature which had shelved the Friedland bills found it difficult to continue opposing the state housing policy now introduced by the Republican governor.

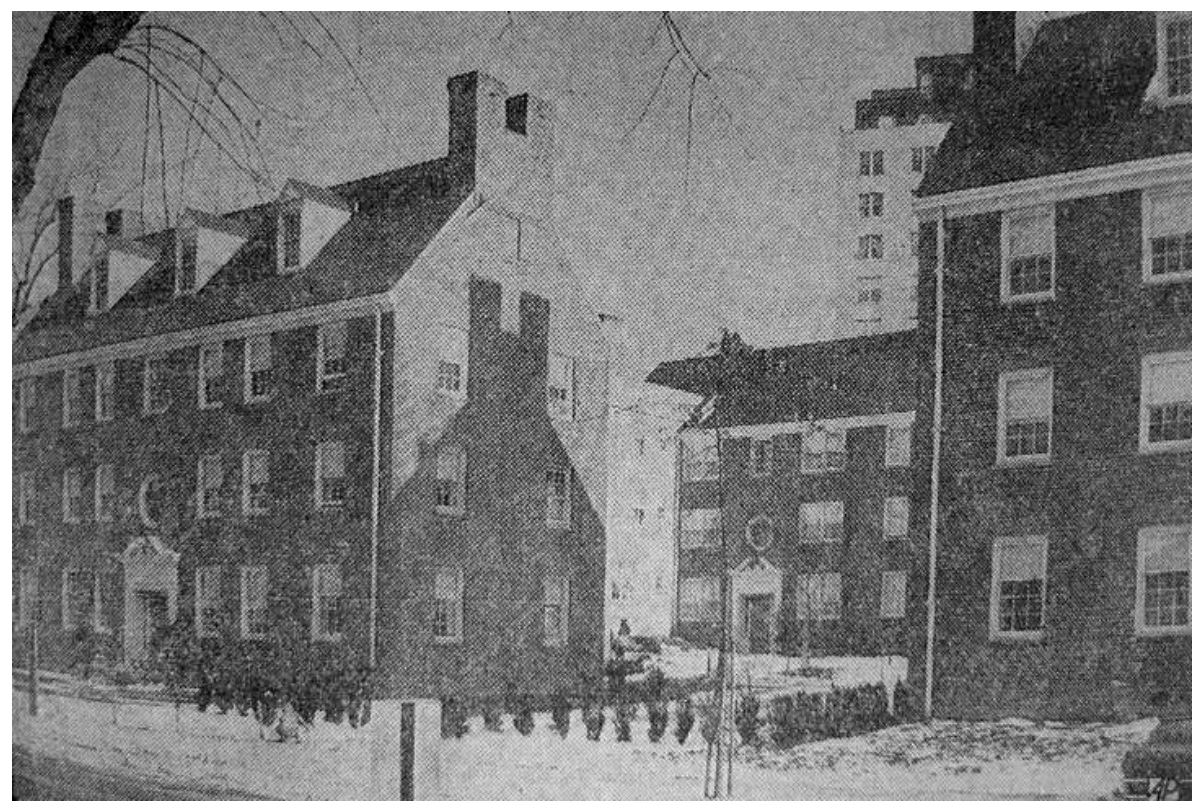

\footnotetext{
29 "Low Rent Housing and Slum Clearance: Special Message of Governor Alfred E. Driscoll," Legislative Bulletin, 1949, 5-10.

30 "New Jersey Association of Real Estate Board, Proposed Suggestions and Ideas for a New Jersey Housing Plan," Folder: Governor's Proposed Housing Program, Box 7A, DCED Commissioner's Files.

31 "For Release to P.N. Papers of Monday, March 28, 1949 and Thereafter," Book 862, Box 078, Driscoll Records.

${ }^{32}$ Elizabeth Daily Journal, 28 March 1949, Book 862, Box 078, Driscoll Records, NJSA. Letter from Commissioner Erdman to Governor Driscoll (17, 25 January; 25 February 1949), Folder: Governor's Proposed Housing Program, Box 7A, DCED Commissioner's Files.
} 


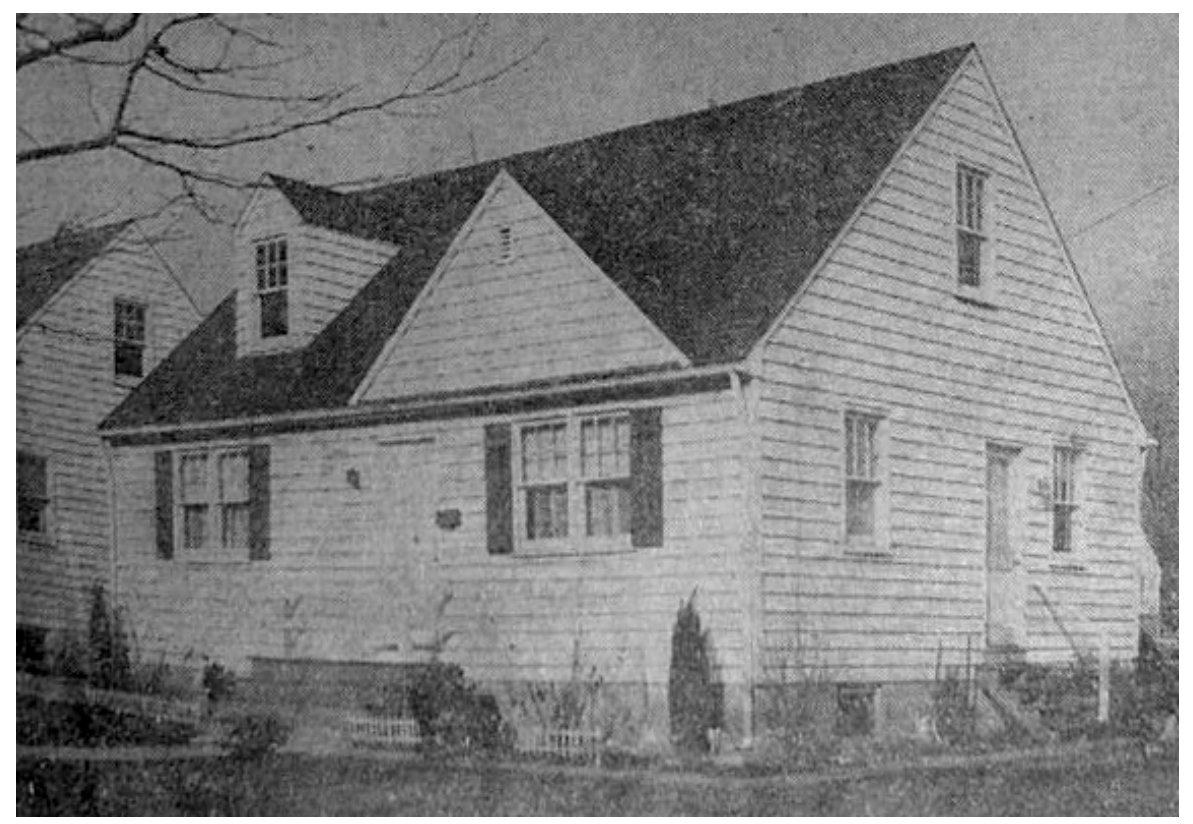

\section{Images of Proposed State Public Housing Projects \\ Sources: “Type of Housing Governor Proposes," Elizabeth Daily Journal, 28 March 1949 [unknown page], Book 862, Box 078, Driscoll Records, NJSA.}

On March 28, 1949, The Driscoll bills (A-45, A-46, A-47, A-48 and A-49) were introduced in the state legislature. The bills inherited the basic structure of the Friedland bills in terms of state loans and subsidies, the complete power of the DCED to manage every aspect of the program including rent levels and qualifications, and the use of state housing bonds as primary financing. There were, however, significant differences.

Advocates of low-rent and high-quality public housing suffered three major setbacks. The Friedland bills appointed only public entities, like local housing authorities, as contractors to implement each housing project, but Driscoll's A-45 bill granted contractors priority in the following order: private builders, co-operatives, [quasi-public] housing corporations, redevelopment companies, municipalities and local housing authorities. This alteration clearly made it difficult for state and local governments to manage the projects directly. A-45 imposed no statutory limitation on the profits of private builders, which would affect rent levels and the quality 
of housing units. ${ }^{33}$ Without limiting their profits, builders could hike rents and skimp on construction costs. Another setback was elimination of the anti-discrimination provision stipulated in the Friedland bills. The DCED could now give silent approval to white resident and local government demands for racial segregation. The last setback was a slum-clearance feature. "The Authority may require," A-45 stated, "that the site on which the project is to be erected is a blighted or slum area," and those who were living on such sites would be given the tenancy eligibility. ${ }^{34}$ This new provision, reflecting demands of the real estate lobby, limited the possibility of constructing state public housing outside of central cities and made potential development more closely resemble federal projects.

The changes did not mean, however, that the Driscoll plan completely jettisoned its public nature. The regulations in the programs, including the rent level and occupant selection, and public financing still distinguished the projects from the private counterparts. Its middle-income orientation remained, too. A-45 appropriated half of total public project units to veterans with children. Thus only half of the state housing program was associated with slum-replacement. The bill actually allowed even greater leeway for lower-middle-income families to qualify than Friedland initially proposed. Unlike the Friedland bill's \$3,500 income ceiling, Driscoll's A-45 bill restricted qualified tenants to "persons or families whose net annual income at the time of admission does not exceed five times the annual rental" including utilities (existing residents with family incomes 25 percent higher than this standard were allowed to stay). ${ }^{35}$ Although the "fiveto-one" criterion was identical to the federal counterpart, the DCED could conceivably set a higher income cap, if the state determined to do so. Families with more than $\$ 3,500$ annual income, for

\footnotetext{
33 "Proposed State Housing Law of 1949," 22, 29.

34 "Proposed State Housing Law of 1949," 23.

35 "Proposed State Housing Law of 1949," 30-31.
} 
example, would be qualified by setting annual rents at more than $\$ 700$. With the expected passage of the Housing Act of 1949, the state government anticipated an expansion of federal low-income projects. Circumstances were much more favorable than previous years for addressing housing issues for the "forgotten one-third." In other words, the state would dedicate itself to build the "second" floor of public housing policy only if the federal and municipal governments made positive efforts to construct the "ground floor" where they had little room for "self-liquidating" operations.

Finally, the Driscoll bills strengthened the financial capability of the state housing program, bolstering its low-rent and high-quality features. In the Friedland bills, the housing projects were only partially tax-exempted and subject to property tax based on the value assessed at the time of property acquisition. The Driscoll bill provided, on the other hand, "all projects constructed, managed, operated or maintained by the Authority under this act shall be exempt from all taxation including but not limited to taxation on real property," notwithstanding any other laws or municipal ordinance. ${ }^{36}$ Also, the Driscoll bills prescribed a new state-wide property tax as the last resort for financing. The bill A-48 provided, "If in any year ... funds ... be insufficient ... there shall be assessed, levied and collected annually in each of the municipalities of the counties of this State a tax on real and personal property" in addition to possible appropriations from the state general funds for the same purpose. ${ }^{37}$ The state-wide property tax under this act would be levied not only in the central cities where there were concentrated housing needs but also in the suburban municipalities that had little interest in having public housing in their own localities. It was

\footnotetext{
36 Ibid.

37 "Proposed Authorization for One Hundred Million Dollar Housing Bond Issue, Subject to Referendum," Legislative Bulletin, 1949, 69-70. The housing bonds, which would take effect if there were a majority of votes in favor of the act at the general election in November 1949, would carry an interest of not more than 3 percent, and would be limited to 35 years (A-48: Section 8, 15, 18).
} 
practically a proposal for permanent redistribution of resources in New Jersey, not through a state tax on income as demanded by the NJ-CIO, but through a state tax on the value of property. This specific taxation proposal had significant political implications, as examined below. Still, the state housing program in the Driscoll bills primarily depended on $\$ 100,000,000$ in state housing bonds, and Driscoll repeatedly explained that the program was "substantially self-liquidating." The state would issue the housing bonds, only if a majority of voters approved the referendum scheduled for November.

Conflicting public opinion towards the Driscoll housing bills was expressed at a public hearing before the Joint Judiciary Committees of the State Senate and the General Assembly held in May. ${ }^{38}$ Proponents of public housing consisted of labor unions, veterans' organizations, tenant leagues, women's associations, some religious groups, African-American organizations, Jewish associations, a social workers' association, and central city governments and their housing and welfare authorities, most of which had joined in the NJHC. They agreed on the necessity for a decent state housing program, with most of them asking for an even more comprehensive program. The executive secretary of the NJ-CIO, in his general support for the goals of the Driscoll bills, demanded a limitation on private company profits, a higher priority on the public agencies as contractors, anti-segregation provisions, and a "Special Citizens' Committee" to advise the Housing Commissioner. ${ }^{39}$ A veterans' organization delegate warned that attempts to construct low-rent and high-quality housing units by using private builders had already failed in a past state emergency program, and a representative from another veterans' organization asked for an exclusion of veteran pensions from income assessments so that the more middle-income veterans

\footnotetext{
38 State of New Jersey, Report of Public Hearing on Assembly Bill Nos. 45 and 48: Before the Judiciary Committees of the Senate and General Assembly, held on May 5, 1949, DOCNJ.

39 Ibid., 38-44. The witness, Stephen J. Moran also represented the New Jersey State Americans for Democratic Action (ADA).
} 
could qualify for the state public housing program. ${ }^{40}$ Vincent J. Murphy, mayor of Newark, despite his general "home rule" rhetoric, identified himself as a proponent for state public housing because Newark, he asserted, desperately needed " 10,000 units of low-rent housing, and 15,000 units for moderate-income families." 41

Meanwhile, the hearing exposed disagreement on the issue of financial resources among its proponents. The New Jersey Association of Housing Authorities, a group of local housing authorities in major cities, maintained that $\$ 100$ million bond and state subsidies as prescribed in the proposed Driscoll legislation were insufficient, and that "a much larger public housing program ... could be financed through the sale of [local] housing authority bonds, secured by a pledge of the State subsidy," which would be appropriated from state general funds. ${ }^{42}$ On the other hand, the chairman of the NJHC, the state-wide coalition of pro-reform groups, insisted that financing the program could be "self-liquidating" and "will not require the imposition of any taxes nor cost the taxpayers of the State any moneys."43 The NJ-CIO failed to obtain the consent of other groups for its plan to implement state income taxes to fund comprehensive social programs in New Jersey. Proponents had failed at achieving consensus on funding resources even a year after the formation of the NJHC.

Suburban municipalities and business groups, such as private mortgage bankers, the real estate industry, building materials industry, and other business associations made up the opposition. They opposed creating a state public housing program. A representative of the New Jersey State League of Municipalities, an organization of high-level municipal officials predominantly from suburban areas, argued that the "fundamental doctrine of home rule" would be flagrantly violated

\footnotetext{
40 Ibid., 36-38, 45-48.

41 Ibid., 8-14.

42 Ibid., 126-139.

43 Ibid., 20-36.
} 
by the provisions. He also criticized A-48 for its "unfair and unjust" tax proposal on the ground that "many of the municipalities will not participate in the program," implying that most of the suburban political leaders had no will to build state public housing in their localities even if the measure took effect. ${ }^{44}$ An agent of the New Jersey Savings and Loan League, representing the private housing loan business, opposed the proposed property tax that would be imposed on those "who presently are acquiring their homes ... [and] many hundreds of thousands of others who are hopeful of reaching the status of self-supporting home owners in the future." He also maintained that public housing policy "should be rigidly confined to the purpose of eradicating slum conditions" because otherwise the state and local governments would "go into the general real estate and mortgage business." 45 Similarly, a representative from the New Jersey Association of Real Estate Boards argued, "we do not think it is fair to the property owners to have to carry the burden of public housing ... [We] are not ... against slum clearance nor housing for the underprivileged ... but we do oppose [this] public housing ... this bill has no rent ceiling." 46 The president of the New Jersey Lumbermen's Association insisted "a nation of home owners is the surest way to preserve our American way" and urged the legislature to "amend these bills so as to provide State aid to the great masses of families in the lower income groups to own their own homes" 47 Business interests outside housing-related industries joined the oppositions. The New Jersey Taxpayers Association, which had on its board executives of major corporations such as Westinghouse, Esso Oil, Johnson \& Johnson, and Campbell, expressed opposition to the bills because "the extent and nature of the present need are not known." The Association was a pressure group that called for overall tax reduction as well as support for the doctrine that "any plans to

\footnotetext{
44 Ibid., 66-70.

45 Ibid. 110-113.

46 Ibid., 83-85, 99-103.

47 Ibid., 79-83.
} 
increase taxes be deferred until there has been broad-scale effort to economize in the cost of government." 48 Business and suburbs allied against the state public housing program. Many of them accepted residual public housing for the poorest but showed fierce opposition to middleincome public housing. Together, they criticized the state-wide property tax proposition in the name of current and prospective homeowners.

Despite the ever-increasing gap between the proponents' demand for a more comprehensive program and opponents' criticism of middle-income public housing, on June 13, 1949 the state legislature, after some revisions to appease conservative forces in the state Senate, enacted the New Jersey State Housing Law (Chap. 303, 304, Laws of 1949) by a vast majority and with a bipartisan vote. ${ }^{49}$ Revisions included giving the DCED's Housing Council, appointed by the governor, the power to make the most important decisions to which the Authority (the public housing department of the DCED) was subordinated; deleting A45 section 13 which allowed the state Authority to override municipal zoning and ordinances; limiting the aggregate amount of all expenditures, including loans and subsidies, to $\$ 100$ million; and prohibiting acceptance of any application for these expenditures after July, 1952. ${ }^{50}$ There is no doubt that the latter two revisions would significantly fetter the state housing program. Still, it was a great legislative breakthrough that the State Housing Law entitled the state government to launch a new public housing program that would accommodate lower-middle-income families. The only reservation was that the state could not embark on this great enterprise until voters approved the $\$ 100$ million state housing bond referendum in November, 1949.

\footnotetext{
48 Ibid., 106-110. New Jersey Taxpayers Association, Better Government: 1950 Platform of the New Jersey Taxpayers Association, NJSL, 2.

49 Minutes of . . the General Assembly, 1949, 1057-1058. Journal of the . . Senate of the State of New Jersey, 1949, 936-937.

50 "An Act concerning housing for the people of the State and making appropriations therefor," Acts of the State of New Jersey, 1949 (Chapter 303), 932-934, 940-941, 955, NJSA.
} 


\section{The Referendum, November 1949}

Following passage of the State Housing Law of 1949, advocates of the state public housing program had reasonable hope that voters would approve the $\$ 100$ million bond referendum. Because the vast majority of the Republicans and most of the Democrats in the state legislature endorsed the law, a major partisan campaign against the housing bond was unexpected. Several local newspapers expressed views sympathetic to the state public housing initiative. The Asbury Park Press editorial on June 13 stated, "We are not impressed with the argument of those who oppose ... issuing bonds to provide decent housing." "Whatever doubt might exist as to the ultimate outcome at the polls," the Trentonian argued the following day, "the fact remains that New Jersey at least has taken a progressive stand on housing relief which undoubtedly was warranted by facts and necessity." The Atlantic City Press urged on June 24, "We hope that voters will give the green light to the 100-million-dollar bond issue." ${ }^{51}$ Moreover, the Federal Housing Act of 1949 enacted in early July provided further support to the proponents by guaranteeing their prospects of new federal public housing projects in the poorest areas. The New Jersey State Federation of Labor at last joined the NJHC to endorse the federal and state public housing programs. ${ }^{52}$ The Housing Commissioner of the DCED was preparing to launch the program in anticipation of the passage of the housing bonds. ${ }^{53}$

The result of the referendum on November 8, 1949, however, crushed the proponents' hopes. Approximately 31.9 percent of New Jersey's total registered voters voted in the referendum, and 62.5 percent of voters said "NO" to the state housing bonds. ${ }^{54}$ Why did the New Jersey

\footnotetext{
51 New Jersey Newspapers Support State Housing Program," "Folder: Governor's Proposed Housing Program, Box 7A, DCED Commissioner's Files.

52 “Let's Build Our Home,” New Jersey Labor Herald, June 1949, 8, New Jersey Information Center, Newark Public Library, Newark, NJ.

53 Letter from State Treasurer Walter T. Margetts, Jr. to Commissioner Charles R. Erdman, Jr. (Oct. 28, 1949), Folder: Governor's Proposed Housing Program, Box 7A, DCED Commissioner's Files.

54 Division of Election, Department of State, State of New Jersey, Election Returns, 1910-1997: Public Questions,
} 
electorate reject the housing bonds necessary to put the state public housing scheme in action $?^{55}$ A careful examination of social and political developments at the time will reveal three major factors that contributed to the voting outcome. First, anti-tax sentiments among homeowners, urged on by opponents, shaped an unfavorable climate to the state public housing program. Second, white residents' desire to protect property values by maintaining racial homogeneity fostered hysteria and localism against the state public housing program. Finally, proponents, weak in their response to the negative campaign of their resourceful opponents, failed to fully awaken public interest in central places. ${ }^{56}$

Two polls held in October demonstrated a drastic shift in public opinion within the month. At the beginning of October, almost two-thirds of respondents supported the housing bond, while only 24 percent opposed it. By the end of the month, support dropped to 48 percent, while opposition grew to 40 percent. ${ }^{57}$ Behind this catastrophe, there was the anti-state-housing propaganda of well-organized opponents. The New Jersey Council for Home Protection (NJCFHP), formed by bankers, real estate groups, private builders, and other big business associations in late September, launched a $\$ 100,000$ negative campaign against the state housing bonds. ${ }^{58}$ The NJCFHP specifically targeted the new state-wide property tax that the State Housing Law

1949, Box 123, Secretary of State - Election Filings and Related Record, NJSA. Bureau of the Census, U.S. Department of Commerce, Table 51, New Jersey, Vol. 2, Census of Population: 1950. The author estimated the turnouts based on total votes and population of the people 21 years old or older. In 1950, there were 3,326,000 residents more than 21 years old in New Jersey, and 1,061,400 cast ballots in the housing bond referendum in 1949.

${ }^{55}$ Friedman shows that in almost every suburban Protestant community about 80 percent of voters rejected the bond, while in every urban African American community nearly 70 percent of voters supported it. Yet, in Catholic and Jewish communities, voting results varied considerably. Religious identity does not explain the voting results. Gordon D. Friedman, Issue, Partisanship and Political Subcultures: A Study of Voting in Statewide Referenda in New Jersey, 1944-1966 (Ph.D. diss., Political Science, University of North Carolina at Chapel Hill, 1970), 28-29, 78, 106, 168171, 189-194, 212.

${ }^{56}$ In this thesis, "central places" mean municipalities with both high population density $[15,000$ per square mile or more] and low homeownership rate [40 percent or less], and "suburbs" mean urban areas [census definition] outside central places.

57 The New Jersey Poll, 6 October 1949; The New Jersey Poll, 27 October 1949.

58 "Oppose, Two Bond Issues: Taxpayers Urge 'No' on Bonus and New Group Hits Housing Plan," Newark Evening News, 22 September 1949, 1-2; "Jersey Will Vote on 3 Bond Issues," New York Times, 6 November 1949, 10. 
mandated as a last resort for financing. The NJCFHP repeatedly played to current and future homeowner concerns for future tax burdens. It argued, "Political public housing never has been and cannot by its very nature ever be self-supporting ... Who would pay the costs incidental to the issuance of the bonds? The taxpayers ... Is there a trend toward more home ownership? Yes, and more public rental housing is contrary to that trend ...it would destroy it [homeownership] by taxing it to death"

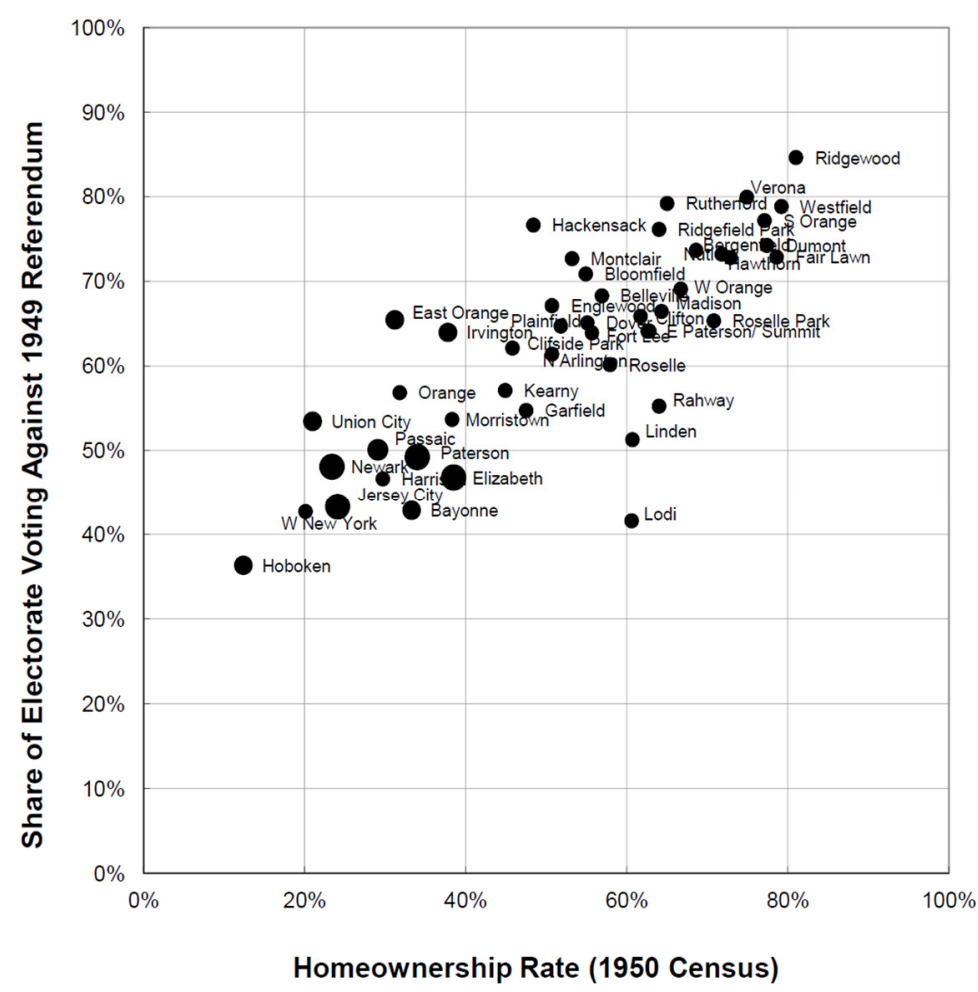

59 New Jersey Council for Home Protection, The Truth about the \$100,000,000 New Jersey Political Housing Scheme, 1949, SNJC.
Figure 1

Correlation: Homeownership Rates and Share of Electorate Voting Against the 1949 Housing Bonds Referendum: Northeastern NJ

Pearson correlation coefficient: $\mathbf{0 . 7 8 5}$

"Northeastern NJ" - Essex, Hudson, Bergen, Union, Passaic and Morris County.

Municipalities of 10,000 or more residents, excluding townships.

Sources: Division of Election, Department of State, State of New Jersey, Election Returns, 1910-1997:

Public Questions, 1949, Box 123, Secretary of State - Election Filings and Related Record, NJSA. Bureau of the Census, U.S. Department of Commerce, United States Census of Housing: 1950: General

Characteristics: New Jersey (Washington D.C.: Government Printing Office, 1952).

1949, SNJC. 

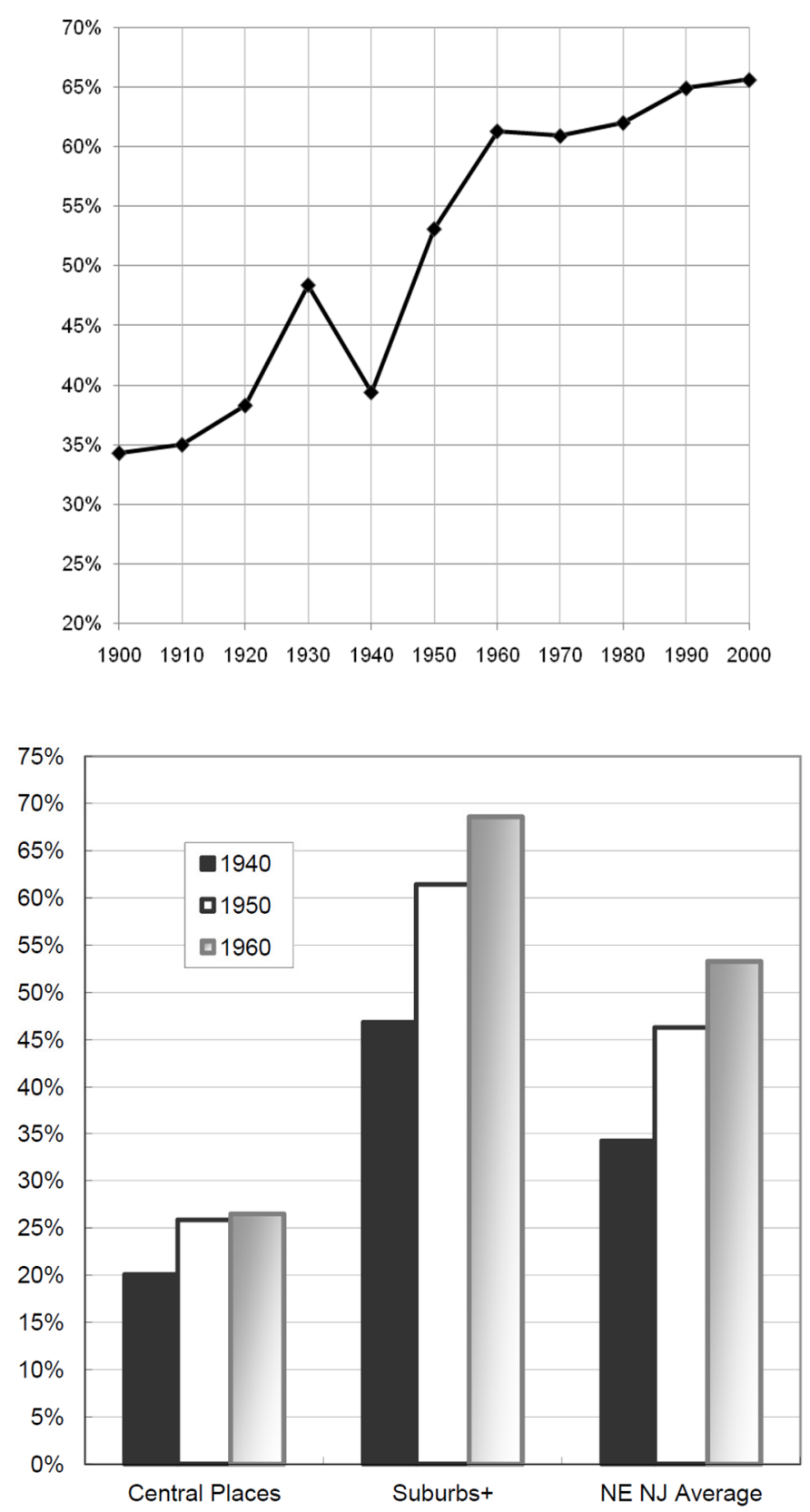

Figure 2

Homeownership Rates in New Jersey: Historical Trend, 1900-2000

Sources: Historical Census of Housing Tables: Homeownership, Census of Housing, U.S. Census

Bureau.

[URL] www.census.gov/hhes/www/ housing/census/-historic/owner.html
Figure 3

Homeownership Rates in Central Places and Suburbs + , Northeastern NJ, 1940-60

"Central Places" - Municipalities with high population density $(15,000$ per sq mile) and low homeownership rate (40 percent or less): Newark, East Orange, Irvington, Orange, Jersey City, Hoboken, Union City, West New York, Paterson and Passaic.

"Suburbs + " - Urban areas outside central places (suburbs) and rural areas. Rural areas represented only

3.8 percent of northeastern $\mathrm{NJ}$ population in 1950.

Sources: Bureau of the Census, U.S. Department of Commerce, United States Census of Housing: 1940; 1950; 1960: New Jersey.

The opponents' anti-tax propaganda effectively functioned only because they found a favorable audience among homeowners and prospective homeowners. Homeowners actually accounted for most of the NO votes. Figure 1 shows a clear correlation between homeownership 
rates and votes to reject the referendum. ${ }^{60}$ Homeownership rates were more than 50 percent in most of the municipalities where over 60 percent of voters rejected the proposal. ${ }^{61}$ Almost every municipality where more than half of voters accepted the proposal had homeownership rates below 40 percent. It was also a time when the rate of homeownership in New Jersey was drastically increasing [Figure 2]. Homeownership rates in suburban areas rose to over 60 percent by the end of the 1940s [Figure 3]. Many of the people moving to suburbs at that time were working-class whites who had never had a chance to own a house before. In 1940, about 44 percent of blue-collar and service workers in northeastern New Jersey resided in suburban areas. The proportion became 52 percent by 1950, outstripping those in central places, and 59 percent by 1960 [Figure 4]. The vast majority of these migrants were white [Figure 5]. Workers who for the first time achieved automatic pay raises, fringe benefits, and had access to seniority rights, a form of "corporate welfare," became relatively stable income earners, enabling them to acquire home mortgages. ${ }^{62}$ Because property taxes were based on property values rather than income, proposed property tax possibly made working-class homeowners, including those who were in the process of achieving homeowner status, feel unfairly overtaxed. Some working-class homeowners who earned less than middle-class homeowners but had more property than working-class renters would likely view the tax as unfair. This difference in tax burden between homeowners and renters would not have occurred, if the NJ-CIO's equitable income tax proposition had been adopted. Anti-taxation

\footnotetext{
60 The Pearson correlation coefficient between X (homeownership rate) and Y (share of electorate voting against the 1949 referendum) of Figure 1 is 0.785 . This indicates that homeownership rate had a statistically stronger correlation with $\mathrm{Y}$ than other available $\mathrm{X}$ variables, including share of non-white occupant (-0.067), population density (-0.569), substandard housing rate (-0.718), and median income (0.727).

61 In 1950, northeastern New Jersey - Essex, Hudson, Bergen, Union, Passaic and Morris Counties - accounted for nearly 62 percent of the state's total populations, and 33 percent of the area's populations resided in the four largest cities - Newark, Jersey City, Paterson, and Elizabeth. Bureau of the Census, U.S. Department of Commerce, United States Census of Population: 1950, New Jersey (Washington D.C., Government Publishing Office).

62 Nelson Lichtenstein, "From Corporatism to Collective Bargaining: Organized Labor and the Eclipse of Social Democracy in the Postwar Era," in The Rise and Fall of the New Deal Order: 1930-1980, ed. Steve Fraser and Gary Gerstle (Princeton NJ: Princeton University Press, 1989), 140-145. Sanford M. Jacoby, Modern Manors: Welfare Capitalism Since the End of the New Deal (Princeton NJ: Princeton University Press, 1997), 214-220.
} 
sentiment among current and prospective homeowners became the major motivation for voting against the housing bond proposal.

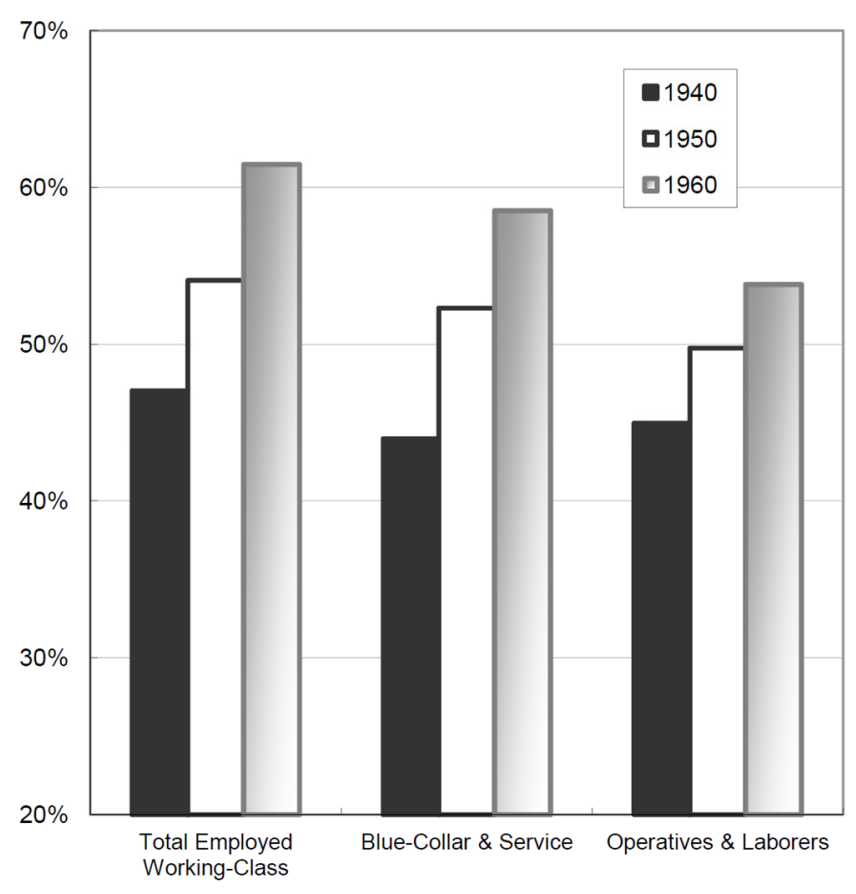

Figure 4

Proportion of Working-Class Living Outside Central Places,

Northeastern NJ, 1940-60

[Working-class living outside central places / Total working-class population]

"Total Employed Working-Class" blue-collar (laborers, operatives, craftsmen \& foremen), farm workers, service workers including domestic service, and nonprofessional white-collar (clerical \& sales).

"Blue-Collar \& Service" - workingclass population excluding whitecollar.

Sources: Bureau of the Census, U.S. Department of Commerce, United States Census of Population: 1940; 1950; 1960: New Jersey.

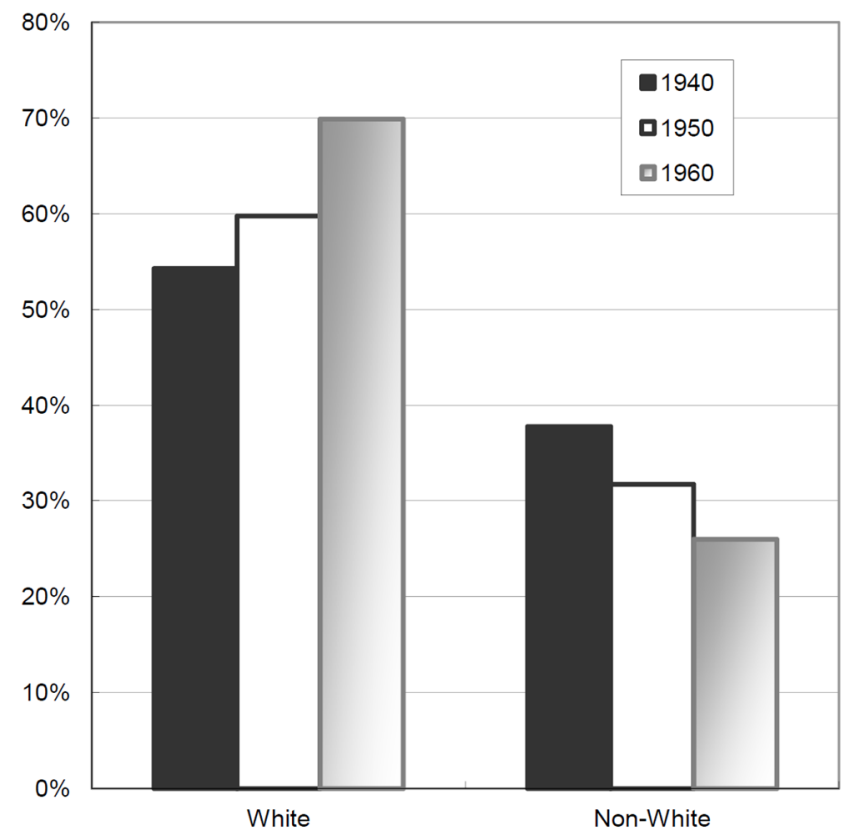

Figure 5

Proportion of White/Non-White Living Outside Central Places, Northeastern NJ, 1940-60

[White/Non-white living outside central places / Total white/nonwhite population]

Sources: Bureau of the Census, U.S. Department of Commerce, United States Census of Population: 1940; 1950; 1960: New Jersey. 
The second factor in the rejection of the referendum was the politics of racial exclusion that had produced an anti-public-housing sentiments among white residents especially along central-suburban borders. In East Orange, located between Newark and its suburbs, only 31 percent of residents owned their own houses. Despite the low rate of homeownership in the city, 66 percent of voters rejected the referendum. This puzzling result can be explained by understanding white residents' concerns about public housing as a threat to imperil the values of their homes. ${ }^{63}$ When migration of wealthier African Americans into East Orange became visible after World War II, white residents, 90 percent of the city's total population, showed fierce resistance to their new neighbors. ${ }^{64}$ To prevent further migration and the development of African American communities, the city began a controversial redevelopment plan. It designated already existing African American neighborhoods as "blighted" and in need of redevelopment. The city then gentrified the entire area making it affordable only for a white "high type" population. ${ }^{65}$ The friction between white East Orange residents and the state came to the fore in early 1949, when the National Association for the Advancement of Colored People (NAACP) filed a lawsuit against East Orange's racial segregation practice, which prevented African Americans from entering into the State Veteran's Emergency Housing Project. The New Jersey Superior Court acknowledged the practice as illegal, and later the state even pressured the city by threatening to terminate the contract unless East

\footnotetext{
${ }^{63}$ In Detroit, white homeowners, including many union members, viewed public "negro housing" as a threat to their communities. On the same day, in 1949, as the New Jersey referendum, they provided a victory to an anti-publichousing Republican in the mayoral race. Thomas J. Sugrue, The Origins of the Urban Crisis: Race and Inequality in Postwar Detroit (Princeton, NJ: Princeton University Press, 1996) 5, 81-84, 210-224.

${ }^{64}$ Bureau of the Census, U.S. Department of Commerce, United States Census of Population: 1940, 1950, 1960. In Chicago, after 1945, there were similar resentments among and resistance from white residents who saw black pioneers moving beyond racial borders into their white neighborhoods. Arnold R. Hirsch, Making the Second Ghetto: Race and Housing in Chicago, 1940-1960 (Chicago: The University of Chicago Press, 1998) 28-38.

${ }^{65}$ Lizabeth Cohen, A Consumers' Republic: The Politics of Mass Consumption in Postwar America (New York: Vintage Books, 2004) 216-217, 417; "Release by Branch of the Oranges" (17 November 1945); "Memorandum: East Orange Housing Situation" (4 January 1946); "Memorandum: East Orange Housing Situation" (25 January 1945); "Letter from Marian W. Perry to Catherine Bauer" (20 March 1946), NAACP Legal Files: 1940-1955: Housing: East Orange, N.J., 1945-1947.
} 
Orange stopped the discriminatory practices. White residents viewed this state action as a threat to their community values because racially equitable state housing projects would accelerate African American movement into their communities. ${ }^{66}$ When the state housing bond was proposed, many residents were well aware of the consequences of public housing expansion despite that the State Housing Law did not explicitly prohibit discrimination. ${ }^{67}$

In many suburban municipalities distant from central places, racial exclusion was even more thoroughly enforced through zoning and housing ordinances. As evidenced afterward in the Southern Burlington County NAACP v. Mount Laurel Township case, "home rules" kept lowincome residents out of many white communities in New Jersey. Most of these racially monolithic communities held to "localism," where homeowners pursued public welfare within their communities by allocating tax revenue only for local benefits. Therefore, they had little intention to allow public housing projects inside their communities, nor would they tolerate attempts to relocate their resources to the state or federal governments for broader-scale welfare, such as the state public housing program. ${ }^{68}$

Anti-tax momentum among current and prospective homeowners, along with anti-public housing hysteria and the localism of homogeneous white communities, were key factors in the defeat of the housing bond proposal. While these explain reasons why many voters voted NO, it does not fully clarify the unexpectedly small number of voters who supported it. In 1949, nearly

66 "Summary Minutes of Quarterly Session on Mar. 26, 1949," NAACP Branch and Geographical Files: 1940-1955: New Jersey State Conference, 1949; "Branch Opposes Jim-Crow City Planning in East Orange Meeting" (21 March 1946), NAACP Legal Files, op. cit. "Court Bans Bias In East Orange Housing," New Jersey CIO News, February 1949, 3; "Negroes, Whites Together: Veterans Families to Live in Same Unit in at least One East Orange Housing Project," Newark Evening News, 9 June 1949, 28.

67 "Housing Program - Scott Bagby's letter to John R. Burnett - Executive Office Inter-Communication" (29 April 1949); "Comment on letter of Scott Bagby: From Commissioner Erdman to Governor Driscoll" (3 May 1949), Book 1183-1184, Box 109, Driscoll Records.

${ }^{68}$ Michael N. Danielson, The Politics of Exclusion (New York: Columbia University Press, 1976) 4, 13-14, 27, 3435, 44-46, 79, 93; Lizabeth Cohen, op. cit. 228-234. 
half of New Jersey's working-class populations still resided in central places, and corporate welfare systems did not cover many unorganized workers. Yet, proponents failed to evoke public interest in their own strongholds. To understand fully the defeat of the referendum, we need to examine the proponents' own weaknesses.

Proponents had two major weaknesses. First, they failed even among themselves to build consensus on how they would finance the housing. NJHC members split on the issue from its inception, failing to pursue the NJ-CIO's state income tax proposition that would not impose a division between urban renters and moderate-income homeowners. Therefore, they were unable to stake out an alternative financial vision to the Friedland and Driscoll bills, nor could they counter opponents' anti-tax campaign with a larger picture of fair financial redistribution. ${ }^{69}$ Second, they failed to build grass-roots movements to arouse public interest in communities and workplaces. Although the NJ-CIO was active in its public relations and lobbying on housing reforms, activities at the local level were few. Before the referendum, the NJ-CIO Political Action Committee (NJCIO-PAC) provided only one advertisement for local newspapers and a few direct mail communications to union members, and it organized no mass meetings or marches. ${ }^{70}$ Many union locals were indifferent to broad social programs, like state public housing. Their indifference restrained the scope of the NJ-CIO-PAC's activities. Some locals even sabotaged political actions by not sending their rosters to the NJ-CIO-PAC. Less than half of NJ-CIO locals, mostly the Textile Worker locals, made contributions to the NJ-CIO-PAC. The shrinking total budget of the NJ-CIOPAC, \$26,000, was far from the NJCFHP's \$100,000 anti-public-housing campaign budget.

\footnotetext{
69 Letter from Winston Paul to Commissioner Erdman (7 October1949), Folder: Governor's Proposed Housing Program, Box 7A, DCED Commissioner's Files.

70 New Jersey State CIO Political Action Committee, The Effectiveness of PAC in New Jersey: A Comprehensive Study of the Methods, Problems and Results Obtained in New Jersey during the 1950 Congressional Election Campaign, January 1951, 17-21, SNJC.
} 
Without the collaboration of local unions, the NJ-CIO-PAC was unable to organize a mass movement that countered the funding power of its opponents. ${ }^{71}$

Thus proponents failed to raise public interest in their home grounds, clearly shown by lower voting rates in central places than suburbs. ${ }^{72}$ In northeastern New Jersey, the turnout in central places was 25.4 percent, 7.8 percent lower than the average of all other areas. Only 18.5 percent of the electorate in Newark went to the ballot. ${ }^{73}$ The political campaign in the central places, where 51 percent of voters approved the housing bond, was unsuccessful considering that, on the same day, nearly 80 percent of New York City voters supported New York State's additional $\$ 300$ million housing bond proposal and another proposition to increase maximum subsidies in the New York State housing program from $\$ 13$ million to $\$ 25$ million per year; both of them would eventually help the city's housing programs. ${ }^{74}$ In Newark's most intensely organized workingclass communities (Wards 1, 9, and 13) the proportion of Yes votes for the housing bond was no more than 50 percent, amazingly 3 percent lower than the average for the entire city. ${ }^{75}$ One month before the referendum, a local pollster noted, "a large number of voters say they know little or nothing about the three bond issues ... unless someone takes the trouble to give them a lot more

71 Ibid., 16-17, 50-53, 62-63. The Cold War and anti-communism also undermined the political movements of organized labor, as shown by the expulsion of the United Electrical, Radio and Machine Workers (UE) from the CIO in 1949. In June 1949, the UE's locals in Newark and other urban areas petitioned in their workplaces, which was a rare case of a union local active on the issue of the state public housing. Petition from James McLeish (president of UE at Newark) to Governor Alfred E. Driscoll, Book 391, Box 034; Book 422-423, Box 037, Driscoll Records.

72 The total numbers of votes cast on the state housing program was 1,061,381, which was lower than any other ballot on the same day $-1,718,788$ on gubernatorial race, $1,175,417$ on veterans' bonus, and 1,147,973 on public hospital construction.

73 Division of Election, Department of State, State of New Jersey, Election Returns, 1910-1997: Public Questions, 1949, Box 123, Secretary of State - Election Filings and Related Record, NJSA. Bureau of the Census, U.S. Department of Commerce, United States Census of Population: 1950: Volume 2 Characteristics of the Population: Part 30 New Jersey (Washington D.C., Government Publishing Office, 1952).

74 "Vote for Appeals Judge, Borough Presidents, Amendments; Results in the Suburbs," New York Times, 10 November 1949, 7; "Dewey Signs Bills on Public Housing," New York Times, 23 February 1949, 20.

75 New Jersey State CIO Political Action Committee, op. cit., 31 [Table 24]. State of New Jersey, Election Returns: Public Questions, 1949. 
information about why the money is needed ... [they] will join the large "non-voter' group." 76 The forecast became reality; it only took 20 percent of the New Jersey electorate to defeat the housing bond proposal. ${ }^{77}$

\section{Conclusion}

While homeownership in suburban New Jersey had already been expanding at the end of the 1940s, significant numbers of lower-middle-income people in urban areas were left behind when they missed out on the benefits from FHA mortgage insurance or conventional low-income public housing projects. Another New Deal was, therefore, pursued by housing reform advocates addressing the forgotten one-third." The solution demanded by New Jersey organized labor, veterans' organizations, minority groups, and central city governments attempted to upgrade and expand public housing. The New Jersey state public housing program, enacted as the State Housing Law of 1949, was an innovative, though limited, effort of building such new public housing. It would have made public housing option more attractive for the state's lower-middle-income residents. The program was incompatible with the business-backed solution of creating a mass homeownership society. Private banks, real estate, building, and other business interests allied with suburban political leaders fiercely attacked the state public housing program. It was New Jersey voters, however, who refused to approve $\$ 100$ million in housing bonds, the linchpin of the program, at the referendum in November, 1949. The primary reason for voter rejection was the shaping of anti-public housing sentiment among current and prospective homeowners, including former proponents of New Deal politics. The political shift was galvanized by the concern of increased tax burdens on these homeowners. A new state-wide property tax for financing the state housing program was especially problematic for suburban homeowners, who had no inclination to

\footnotetext{
76 The New Jersey Poll, 6 October 1949, 2; 27 October 1949, 1.

77 State of New Jersey, Election Returns: Public Questions, 1949. Bureau of the Census, Census of Population: 1950.
} 
invite public housing in their communities or to relocate their local resources to urban areas, and for some working-class homeowners, who had tight budgets. To be sure, well-healed opponents played a significant role. Yet, more important, the widespread acceptances of these concerns demonstrated that many people in New Jersey, including the white working-class, were being captured by a new American way of life - pursuing private homeownership in the suburbs rather than reforming urban dwelling environment and relying much more on private than public welfare. The disappearance of public support nationally and political reversal of Congressional Democrats on the issue of federal loans to private middle-income cooperative housing proposed in 1950 can be explained in the same context. ${ }^{78}$ Second, the politics of racial exclusion created an even more unfavorable public climate. On city-suburb borders, white majorities viewed the possible influx of African Americans through state housing projects as a major threat to their communities and property values. The New Jersey state housing program itself lost much of the potential to break the racial status quo. The Driscoll version included a slum-replacing feature and jettisoned the antidiscrimination provision, and the final compromise salvaged local "home rules." Nevertheless, white residents who no longer viewed public housing as benefitting themselves easily demonized "black" public housing. Finally, proponents' failure to persuade and evoke public opinion, due to lack of consensus on an alternative tax proposal, particularly general income tax reform, and weakness of their grass-roots movement, such as union locals' involvement, resulted in an even lower Yes vote, especially in the central places, which produced a small turnout. All these factors contributed to the devastating defeat of the housing bond proposal. New Jersey thereafter went straight into the familiar phenomenon of social division: prospering suburban homeowner communities and deteriorating inner cities. While many suburban homeowners benefitted from

78 Richard O. Davies, op. cit. 116-121. 
FHA mortgage protection, other urban residents, largely non-white, were left behind in substandard housing markets, and only small numbers of the lowest-income families qualified for stigmatized federal public housing projects. In the 1950s, the proportion of substandard housing units increased in central places, and only 31 out of 567 municipalities constructed public projects that altogether accommodated only 13,300 households [Figure 6$] \cdot{ }^{79}$ The loss of a postwar version of the New Deal - majority-oriented public housing - in the late 1940s was at least partially responsible in New Jersey for subsequent residential disparities and segregation perpetuated by the two-tier housing policy. ${ }^{80}$

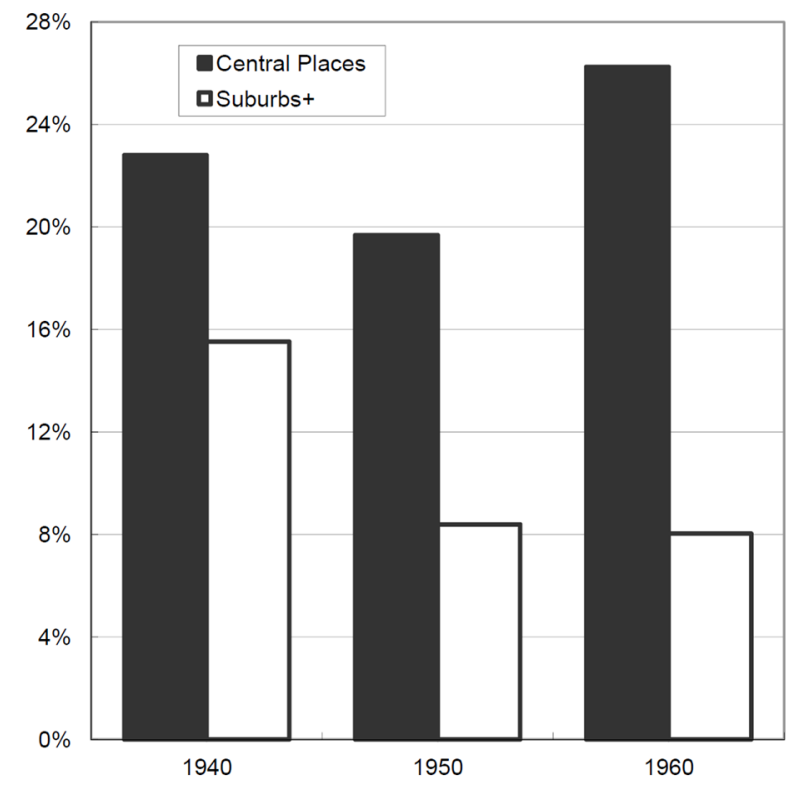

Figure 6

\author{
Rates of Substandard Housing Units \\ in Central Places and Suburbs+: \\ Northeastern NJ, 1940-60 \\ "Substandard Housing Units" - \\ Residential units that need major \\ repairs [1940] or dilapidated [1950] \\ or those with no private bath, no \\ toilet, or no running water.
}

[Sources] Bureau of the Census, U.S. Department of Commerce, United States Census of Housing: 1940; 1950; 1960: New Jersey.

Keisuke Jinno earned a Ph.D. in History from The Graduate School and University Center, City University of New York (2017). Research interests include US history, Japanese history, labor history, social policy, politics.

79 DCED, N.J., Housing and Dwelling Units: 1950-1959. NJSL. Bureau of the Census, U.S. Department of Commerce, United States Census of Housing: 1940; 1950; 1960: New Jersey.

${ }^{80}$ Arnold R. Hirsch, op. cit. 253-256. 